OPEN ACCESS

Edited and reviewed by: Akio Adachi,

Kansai Medical University, Japan

${ }^{*}$ Correspondence:

Jeremy R. Thompson

Jeremy.Thompson@mpi.govt.nz

Specialty section:

This article was submitted to

Fundamental Virology,

a section of the journal

Frontiers in Virology

Received: 31 March 2021 Accepted: 08 April 2021 Published: 07 May 2021

Citation:

Thompson JR (2021) Fundamental

Virology: Same Objectives, Changing

Tools. Front. Virol. 1:689478.

doi: 10.3389/fviro.2021.689478

\section{Fundamental Virology: Same Objectives, Changing Tools}

\author{
Jeremy R. Thompson * \\ Plant Health and Environment Laboratory, Ministry of Primary Industries, Auckland, New Zealand
}

Keywords: expanding virome, endogenization, nanotechnology, high-throughput sequencing, imaging, diagnostics, vaccines, taxonomy

\section{CONTRIBUTIONS OF BASIC VIROLOGY TO BIOLOGY}

Despite their biological limitations, viruses have provided us with an incredible wealth of information on the higher organisms they infect. Seen in the best of light, viruses provide us with the necessary tools to discover the essential building blocks of life. As our knowledge and appreciation of virus diversity grows we appear to be at a tipping point in how we perceive them; from simply being agents of disease to basic components of life-mobile genetic elements that enrich all life forms for better and worse.

History shows that fundamental research of viruses has been essential in the development of our understanding of molecular and genetic processes. Studies in the late fifties, sixties and seventies on the T4 bacteriophage were critical to solving the mysteries of the genetic code with discoveries of the triplet nature of the genetic code (1), non-sense codons [see Stahl (2)] and the collinearity of the gene with the polypeptide chain [see Brenner (3)]. As the tools of virology and the number of known viruses multiplied so too did the palette of techniques used to decipher the molecular mechanisms of the cell; contributing in the seventies to the elucidation of RNA polyadenylation (adenovirus and polyomavirus) [see Edmonds (4)], mRNA capping (reovirus) [see Furuichi and Shatkin (5)], RNA splicing (adenovirus) [see Berk (6)], tyrosine kinases (retrovirus) [see Hunter (7)], and reverse transcriptases [see Coffin and Fan (8)]. Our understanding of RNA and its unique structural properties were further expanded in the eighties by the discovery in plants of hammerhead ribozymes (secovirus satellite and avsunviroid) $(9,10)$ and pseudoknots (tymovirus) (11).

Indeed, staying within the plant realm, the transformative effect that basic research in virology has had on biological concepts is however probably best exemplified by tobacco mosaic virus, the first virus ever to characterized as such by Beijerinck (12) and the first to be purified by Stanley (13); work that led to its macromolecular dissociation and reconstitution and the first evidence that the RNA alone (not protein) had biological activity and was the "genetic material" (14). This physical dissection of its virions was to provide the scientific community with one of the best models of macromolecular organization and the foundation of nanobiotechnology.

\section{THE CHALLENGES AND OPPORTUNITIES}

The negative effects of humans' continued encroachment on and exploitation of the natural world is becoming all the more painfully evident. Viruses are continually evolving threatening our species health and those species we depend on for survival. In humans, viruses make up over half of all emerging diseases and cause $10-20 \%$ of cancers $(15,16)$ and yet, if used responsibly they could serve as an ally in a multitude of applications; from gene therapy (17) and nanotechnology (18) to cross protection (19) and vaccines (20).

Critical to our ability to utilize our collective knowledge across an ever growing landscape of specialty subjects that are used to understand basic virology will be how we synergically 
communicate across these disciplines. Such processes should nurture more creative thinking and problem solving. However, without access to the right resources and strategies we are potentially exposing ourselves to the risk of siloing our knowledge as we try and keep up with the diversification of technologies.

\section{AN EXPANDING VIROME}

A good example of this phenomenon is the rapid acceleration in our understanding of the Earth's virome because of advances in high throughput sequencing. Yearly, we are accumulating exponential amounts of biological sequence information (21) taken from specific organisms and metagenomic studies all of which provides a wealth of information on known circulating viruses but also untapped information on unknown viruses. Expertise in storing, accessing and manipulating this information is outside the comfort zone of most traditional virologists who rely on bioinformaticians. Full analysis of these datasets in search of novel inferred biological patterns and the classification of viral taxa leading to the development of testable hypotheses can only be achieved by strengthening the interactions between computer programmers and virologists. In fact, virus taxonomy itself is at the risk of losing relevance if it fails to keep up with the expanding virome that, in particular, metagenomic studies have uncovered while still recognizing the need for biological verification.

What constitutes a healthy virome and what are the triggers that can shift a symbiotic virus to be pathogenic are still far from clear (22). Likewise, the process of endogenization of virus elements into the host genome is poorly understood but represents a potentially significant driver in eukaryotic genome restructuring and evolution (23).

\section{DEEPER FUNCTIONALITY}

Viruses too are likely to help us uncover deeper genetic functionalities as they are the ultimate biological entity that combines the seemingly incongruent quality of genomic compactness with an ability to manipulate and subvert the complex cellular machinery of higher organisms for their own reproductive benefit (24).

This pressure from accelerating technologies could lead to missed opportunities because of the constant need to integrate the "next best thing" into our research plans. Virology has always harnessed advances in chemistry and physics and this relationship continues unabated. As the range of drugs both real and virtual, new or repurposed, expands so too does the search for antiviral compounds. Nanotechnology, for which viruses will be both potentially the tool and the target, is opening up a whole

\section{REFERENCES}

1. Crick FH, Barnett L, Brenner S, Watts-Tobin RJ. General nature of the genetic code for proteins. Nature. (1961) 192:1227-32. doi: 10.1038/1921227a0 range of applications for research into vaccines, imaging, drug delivery and diagnostics (25). The inevitable (and very distant) outcome, as we learn to manipulate at a smaller and smaller level, will be real-time visualization of all cellular components (26). Systems approaches to virus macromolecular interactions will help in this goal as will novel techniques to in vivo global structural determination (27).

\section{COMMUNICATE OR PERISH}

Despite the astonishing scientific advances of the past enlightened centuries it can often seem that our discoveries only generate more problems and that we are caught in an endless cycle where technology is at the same time both constructive and destructive. This dualistic worldview in itself produces its own collective anxieties that feed public morality driving regional policymaking which in turn can have a significant impact on the directions and freedom of scientific investigative curiosity (28). One only needs to look at how transgenic technologies in agriculture, once hailed as promising a greener generation of crops, to appreciate the often-precarious position of science in the human collective psyche. This challenge is even more acutely felt as we enter an era where scientific misinformation and misinterpretation is rife.

Virologists like most scientists will always find time to fret over a lack of funding or interest in their field. This is especially true for fundamental virology which can often be seen by a wider audience as esoteric and lacking any obvious and immediate benefits. The consequences of the COVID-19 pandemic may soon fade in our collective memory as a period we would all rather forget; and yet, alternatively, it may (and should) provide the necessary wake-up call for a renewed interest and investment in virology research at all levels without an explicit need to justify the ends.

It seems therefore to be more pertinent than ever for fundamental virologists to continue creatively and responsibly exploiting new technologies to uncover more secrets on these fascinatingly miniscule obligate parasites, while at the same time we must learn to actively engage much better with an ever more informed and opinionated public.

\section{AUTHOR CONTRIBUTIONS}

The author confirms being the sole contributor of this work and has approved it for publication.

\section{ACKNOWLEDGMENTS}

Thanks to Peter Palukaitis for discussions during the preparation of this article. 
4. Edmonds M. A history of poly A sequences: from formation to factors to function. Prog Nucleic Acid Res Mol Biol. (2002) 71:285389. doi: 10.1016/S0079-6603(02)71046-5

5. Furuichi Y, Shatkin AJ. Viral and cellular mRNA capping: past and prospects. Adv Virus Res. (2000) 55:135-84. doi: 10.1016/S0065-3527(00)55003-9

6. Berk AJ. Discovery of RNA splicing and genes in pieces. Proc Natl Acad Sci USA. (2016) 113:801-5. doi: 10.1073/pnas.1525084113

7. Hunter T. Discovering the first tyrosine kinase. Proc Natl Acad Sci USA. (2015) 112:7877-82. doi: 10.1073/pnas.1508223112

8. Coffin JM, Fan H. The Discovery of Reverse Transcriptase. Annu Rev Virol. (2016) 3:29-51. doi: 10.1146/annurev-virology-110615-035556

9. Prody GA, Bakos JT, Buzayan JM, Schneider IR, Bruening G. Autolytic processing of dimeric plant virus satellite RNA. Science. (1986) 231:157780. doi: 10.1126/science.231.4745.1577

10. Hutchins CJ, Rathjen PD, Forster AC, Symons RH. Self-cleavage of plus and minus RNA transcripts of avocado sunblotch viroid. Nucleic Acids Res. (1986) 14:3627-40. doi: 10.1093/nar/14.9.3627

11. Rietveld K, Van Poelgeest R, Pleij CW, Van Boom JH, Bosch L. The tRNA-like structure at the 3' terminus of turnip yellow mosaic virus RNA. Differences similarities with canonical tRNA. Nucleic Acids Res. (1982) 10:1929-46. doi: 10.1093/nar/10.6.1929

12. Beijerinck BM. Über ein Contagium vivum fluidum als Ursache der Fleckenkrankheit der Tabaksblätter. Verhandelingen der Koninklijke Akademie van Wetenschappen Te Amsterdam. (1898) 65:1-22.

13. Stanley WM. Isolation of a crystalline protein possessing the properties of tobacco-mosaic virus. Science. (1935) 81:6445. doi: 10.1126/science.81.2113.644

14. Lewis J. From virus research to molecular biology: tobacco mosaic virus in Germany, 1936-1956. J Hist Biol. (2004) 37:259-301. doi: 10.1023/B:HIST.0000038206.09052.7a

15. Rohr JR, Barrett CB, Civitello DJ, Craft ME, Delius B, DeLeo GA, et al. Emerging human infectious diseases and the links to global food production. Nat Sustain. (2019) 2:445-56. doi: 10.1038/s41893-019-0293-3

16. De Flora S, Bonanni P. The prevention of infection-associated cancers. Carcinogenesis. (2011) 32:787-95. doi: 10.1093/carcin/bgr054

17. Anguela XM, High KA. Entering the modern era of gene therapy. Annu Rev Med. (2019) 70:273-88. doi: 10.1146/annurev-med-012017-0 43332

18. Ding X, Liu D, Booth G, Gao W, Lu Y. Virus-like particle engineering: from rational design to versatile applications. Biotechnol J. (2018) 13:e1700324. doi: 10.1002/biot.201700324
19. Folimonova SY, Achor D, Bar-Joseph M. Walking together: cross-protection, genome conservation, and the replication machinery of citrus tristeza virus. Viruses. (2020) 12:1353. doi: 10.3390/v12121353

20. Vemula SV, Sayedahmed EE, Sambhara S, Mittal SK. Vaccine approaches conferring cross-protection against influenza viruses. Expert Rev Vaccines. (2017) 16:1141-54. doi: 10.1080/14760584.2017.1379396

21. Arita M, Karsch-Mizrachi I, Cochrane G. The international nucleotide sequence database collaboration. Nucleic Acids Res. (2021) 49:D1214. doi: 10.1093/nar/gkaa967

22. Koonin EV, Dolja VV, Krupovic M. The healthy human virome: from virus-host symbiosis to disease. Curr Opin Virol. (2021) 47:86-94. doi: 10.1016/j.coviro.2021.02.002

23. Moniruzzaman M, Weinheimer AR, Martinez-Gutierrez CA, Aylward FO. Widespread endogenization of giant viruses shapes genomes of green algae. Nature. (2020) 588:141-5. doi: 10.1038/s41586-020-2924-2

24. Nagy PD, Pogany J. The dependence of viral RNA replication on co-opted host factors. Nat Rev Microbiol. (2011) 10:137-49. doi: 10.1038/nrmicro2692

25. Campos EVR, Pereira AES, de Oliveira JL, Carvalho LB, GuilgerCasagrande $\mathrm{M}$, de Lima R, et al. How can nanotechnology help to combat COVID-19? Opportunities and urgent need. J Nanobiotechnology. (2020) 18:125. doi: 10.1186/s12951-020-00685-4

26. Touizer E, Sieben C, Henriques R, Marsh M, Laine RF. Application of super-resolution and advanced quantitative microscopy to the spatio-temporal analysis of influenza virus replication. Viruses. (2021) 13:233. doi: $10.3390 / \mathrm{v} 13020233$

27. Li B, Cao Y, Westhof E, Miao Z. Advances in RNA 3D structure modeling using experimental data. Front Genet. (2020) 11:574485. doi: 10.3389/fgene.2020.574485

28. Orben A. The sisyphean cycle of technology panics. Perspect Psychol Sci. (2020) 15:1143-57. doi: 10.1177/1745691620919372

Conflict of Interest: The author declares that the research was conducted in the absence of any commercial or financial relationships that could be construed as a potential conflict of interest.

Copyright (C) 2021 Thompson. This is an open-access article distributed under the terms of the Creative Commons Attribution License (CC BY). The use, distribution or reproduction in other forums is permitted, provided the original author(s) and the copyright owner(s) are credited and that the original publication in this journal is cited, in accordance with accepted academic practice. No use, distribution or reproduction is permitted which does not comply with these terms. 